\author{
RADOSŁAW PIĘTKA \\ Uniwersytet im. Adama Mickiewicza w Poznaniu \\ ORCID: 0000-0001-9239-1149 \\ e-mail: platon@amu.edu.pl
}

\title{
KOMEDIOWA ENEIDA
}

\begin{abstract}
Piętka Radosław, Komediowa „Eneida” (Comedy in Vergil’s Aeneid).
\end{abstract}
The paper deals with the references - hypothetical and/or unquestionable - to comedy and comic conventions in the Aeneid of Vergil. Taking into consideration as many comic constituents as it is possible to retrieve from the Virgilian epic text, I would also like to try to answer the general question concerning supposed influence of these very constituents on the meaning of the whole text of the Aeneid.

Keywords: Aeneid; Vergil; comedy; epic; literary conventions.

Zacząć wypada od wyjaśnienia tytułu niniejszego szkicu. Nie chodzi tu o jakąś parodystyczną, nową wersję Eneidy ${ }^{1}$, ale właśnie o utwór wszystkim doskonale znany - Wergiliuszowy epos heroiczny, a ściślej: jego (potencjalne) komediowe komponenty. Zanim jednak zajmę się komediowym wymiarem największego dzieła Wergiliusza, zasadne wydaje się poczynić, tytułem wprowadzenia, kilka uwag (niewyczerpujących bynajmniej tematu) w związku z szerszym zagadnieniem, jakim jest obecność szeroko pojętych wątków humorystycznych w całym korpusie tekstów poety ${ }^{2}$.

${ }^{1}$ Faktem jest jednakowoż, że drwiono niekiedy z filmowej adaptacji Eneidy; vide komentarz anonimowego internauty do opartego na Wergiliuszowym eposie włoskiego serialu: http://www.filmweb. pl/serial/Eneida-1971-37110/discussion/DO+kitu,194048 (dostęp: 08.05.2019): „to ma być film? moa [sic] siostra zrobiłaby lepszy". Eneida doczekała się także wersji komiksowej (w adaptacji Michaela Lagockiego), ale raczej trudno byłoby tę wersję uznać za szczególnie „komiczną” (vide Kick 2014: 148-157). Już w starożytności pojawiła się natomiast parodia może nie tyle samej Eneidy, co ikonograficznego motywu pochodzącego z mitycznych opowieści o Eneaszu, a mianowicie grupy przedstawiającej samego bohatera, jego ojca oraz syna; właścicielowi willi koło Stabiów (w dzisiejszym Gragnano) spodobało się przedstawić rodzinę Eneasza w postaci zwierząt. Cf. Zanker 1999: 212 (gdzie znajduje się niezbyt czytelna ilustracja oraz nader sugestywny opis malowidła: „,wielcy przodkowie princepsa jako małpia rodzina z psimi głowami i ogromnymi członkami”). Dzieło można obecnie obejrzeć w Narodowym Muzeum Archeologicznym w Neapolu. Więcej na ten temat: de Vos, 1991: 113-123; Clarke 2007: 151-157 (gdzie fresk ten jest traktowany m.in. jako parodystyczne nawiązanie do Eneidy).

${ }^{2}$ Humor, śmieszność, czy nawet komizm to oczywiście kategorie o wiele szersze niż „,komediowość"; próby ich zdefiniowania mają też nader rozległą i złożoną historię; vide np. Dziemidok 
Vis comica nie jest zapewne tą cechą, która przychodziłaby nam na myśl jako pierwsza w związku z twórczością autora Eneidy; co więcej, można zasadnie utrzymywać, że z poetów augustowskich (a może i rzymskich w ogóle) to właśnie Wergiliusz odznacza się najmniej nachalnym poczuciem humoru ${ }^{3}$. Należy jednak przypomnieć, że już domniemany „debiut” poetycki Wergiliusza miał poniekąd żartobliwy charakter: przypisywany młodocianemu poecie dystych, epitafium dla pewnego rozbójnika i zarazem nauczyciela w szkole gladiatorów nazywanego „Ballista”, zawiera dowcip językowy, złoczyńca leży bowiem pod stosem kamieni (w wyniku ukamienowania zapewne), a jego imię oznacza przecież machinę wojenną do miotania tychże kamieni ${ }^{4}$.

Jeśli do autentycznych utworów Wergiliusza zechcielibyśmy zaliczyć epyllion Culex (o komarze, który w postaci zjawy relacjonuje swojemu przypadkowemu zabójcy wędrówkę przez zaświaty), to skromny korpus Wergiliańskich tekstów humorystycznych wzbogaciłby się o poemat heroikomiczny, swoisty odpowiednik pseudohomerowej Batrachomyomachii czy Margitesa ${ }^{5}$. Być może nawet bardziej w tym przypadku jest istotna nie tyle autentyczność obydwu utworów, ile fakt, że tradycja chętnie przypisywała dwóm najważniejszym epikom dwóch literatur antycznych teksty będące parodiami eposu heroicznego. Trzeba

2011: 9-154. W odniesieniu do kultury grecko-rzymskiej vide np. Griffith, Marks 2007: 5-24 (w dalszej części tej książki wyraźnie zresztą dominują interpretacje oparte na tekstach greckich).

${ }^{3}$ Mimo to poświęcono niegdyś temu zagadnieniu całą dysertację; vide Lumsden 1937. Najwięcej uwagi autor kieruje w swojej rozprawie ku odczytywanym jako poemat heroikomiczny Georgikom (w których skądinąd, w księdze drugiej, pojawiają się aluzje do gatunkowych właściwości i historii komedii); Eneidy dotyczą natomiast strony 100-138. W istocie autor rozprawy stara się przywołać wszystkie, nawet niezbyt oczywiste, przypadki zastosowania przez Wergiliusza „lżejszego tonu” (sformułowania typu „lighter tone” czy „lighter vein” powtarzają się kilkakrotnie w tekście pracy). Jeden z francuskich filologów (Richard 1951) forsował również niegdyś nader ekscentryczną wizję Wergiliusza jako humorysty (!). Niezwykle ostrożne opinie na temat humorystycznych podtekstów w Georgikach można natomiast znaleźć np. w: Jenkyns 1993: 247 (pojawia się tu m.in. takie określenie jak ,pponury humor” oraz konstatacja, że w przypadku Georgik mówienie o „humorze” sensu stricto to pewne nadużycie). Ahl (2012: 13-14) odnotowuje z kolei opinio communis o Eneidzie jako dziele niemal całkowicie pozbawionym elementów humorystycznych. Ostatnio ukazała się jednak monografia w całości poświęcona humorowi w Eneidzie, z uwzględnieniem szerokich kontekstów, w tym również (nielicznych) komediowych; vide Bourquin 2019. Za informacje o tej książce oraz tekście Ahla dziękuję Recenzentowi niniejszego artykułu.

${ }^{4}$ Epigram brzmi następująco: „Monte sub hoc lapidum tegitur Ballista sepultus; / nocte die tutum carpe, viator, iter". Interpretację wskazującą na zjadliwy dowcip ukryty w dwuwierszu zaproponowała ostatnio Peirano (2012: 98). Jeśli chodzi o filologiczną analizę dystychu o Baliście, vide Hanssen 1948: 124-125. Nie od rzeczy być może byłoby wspomnieć, że niemal identyczny koncept, oparty na czarnym humorze i ,paradoksie nazwiska”, zastosował w swoim również dwuwersowym „epitafium” polski poeta barokowy Jan Borkowski; wiersz zatytułowany był Żałosna metamorphosis: Mikołaj Rożen od opryszków upieczony. Vide Vincenz 1989: 216.

${ }^{5}$ Warto wspomnieć, że Arystoteles w Poetyce (1448b 38) przypisywany Homerowi poemat jambiczno-heksametryczny Margites traktował jako „komediową” przeciwwagę dla „tragediowej" powagi Iliady i Odysei. 
w tym miejscu dodać, że ,homeryckie” pochodzenie Eneidy samo w sobie nie musiało oznaczać zachowywania całkowitej powagi, skoro i u Homera nieraz odnajdowano pierwiastki komiczne, również w jego dziełach ,zasadniczych”; już w czasach antycznych na przykład zauważono (Pseudo-Longinos w traktacie $O$ wzniosłości IX 15), że opisane w Odysei relacje między domownikami

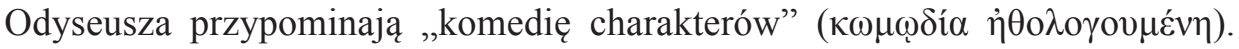
W czasach nowożytnych pierwszeństwo należy w tym przypadku zapewne do Samuela Butlera, który swoją prelekcję zatytułowaną The Humour of Homer wygłosił w roku $1892^{6}$.

Tradycja (w osobie Donatusa) przekazała nam ponadto jeden dowcip opowiedziany przez samego Wergiliusza, czy też przynajmniej coś, co powiedział „per iocum”, à propos Eneidy zresztą ${ }^{7}$ otóż podczas tworzenia swojego ostatniego dzieła Wergiliusz miał stosować następującą metodę: najpierw opracował zarys fabuły prozą, a następnie zamieniał wszystko stopniowo na heksametr. Kiedy napotykał na opór materii, konstruował, aby nie opóźniać pracy, tymczasowe wersy (do których miał zamiar później wrócić, aby je poprawić), czyli, jak to żartobliwie ujął, ,podpórki, które mają podtrzymywać budowlę, aby się nie zawaliła zanim staną tam solidne kolumny". Jak to skomentować? Humor typowo branżowy, czy też nawet nerdowski, jak powiedzielibyśmy dzisiaj. Poza tym nieco żartobliwego nastroju znajdziemy w eklogach ${ }^{8}$, a po dłuższym zastanowieniu moglibyśmy przypomnieć sobie występujące również w Eneidzie ${ }^{9}$

${ }^{6}$ Humorystycznymi pierwiastkami w poezji Homera zajmowali się ponadto m.in.: Sikes (1940); Clarke (1969); Golden (1990); Bell (2007).

${ }^{7}$ Aelius Donatus, Vita Vergilii 23-24: ,Aeneida prosa prius oratione formatam digestamque in XII libros particulatim componere instituit, prout liberet quidque, et nihil in ordine arripiens. Ac ne quid impetum moraretur, quaedam inperfecta transmisit, alia levissimis versis veluti fulsit, quae per iocum pro tibicinibus interponi aiebat ad sustinendum opus, donec solidae columnae advenirent".

${ }^{8}$ Molle atque facetum - taką formułę zaproponował Horacy (Sat. I 10, 44) charakteryzując wczesną twórczość Wergiliusza; w praktyce najprawdopodobniej chodziło tu właśnie o cykl pasterskich eklog (bo mowa jest w tej charakterystyce m.in. o „Kamenach, które lubią wieś”, (,gaudentes rure Camenae"; Sat. I 10, 45), chociaż w grę mogły wchodzić również np. utwory z cyklu Catalepton albo i wspomniany heroikomiczny Culex, którego akcja toczy się przecież na wsi. Jeden z polskich tłumaczy Horacego, Stefan Gołębiowski, nie pozostawił zresztą czytelnikom pola manewru oddając molle atque facetum jako, po prostu, „pieśni pasterskie”. Sformułowanie Horacego, niewątpliwie wskazujące na cechy stylu niskiego, przetłumaczyć można rozmaicie, albo uwypuklając komponent komiczny (np. „frywolnie i dowcipnie”) albo podkreślając walory czysto estetyczne tekstu (np. ,zgrabnie i elegancko"); na temat sensu tej frazy vide, m.in., Jackson 1914; Ogle 1916; Rose 1942: 43-44 (w odniesieniu do humoru w eklogach); Coleman 1975: 141; Halperin 1983: 213-214; Martindale 2005: 145; Tarrant 2007: 72-73; Korpanty 2007. Warto zauważyć, że wedle jednego ze współczesnych interpretatorów Wergiliusza jego twórczość w istocie na zawsze zachowała ów pierwiastek odkryty przez Horacego w Wergiliańskich juweniliach, przy czym sama Eneida miałaby się odznaczać specyficzną ironią, stanowiąc rodzaj przeprowadzonej „na serio” parodii eposów Homera; vide MacKay 1963:160-161.

${ }^{9}$ Skądinąd epos Wergiliusza opisywany był oczywiście częściej jako utwór o charakterze „tragediowym"; cf. np. DeWitt 1930; Panoussi 2009. Tragedie antyczne jednakowoż, trzeba pamiętać, 
przykłady sformułowań, które przy pewnej dozie dobrej woli można uznać za żartobliwe, czy też raczej przykłady pewnej ironii zbliżającej się do dowcipu; takim tonem pobrzmiewa choćby słynna wypowiedź Sybilli na temat „łatwości” wejścia do zaświatów (VI 126-127): „Facilis descensus Averno; / noctes atque dies patet atri ianua Ditis...” - „, Łatwe jest zejście do Awernu, dniem i nocą otwarte są bramy...", a zatem: zapraszamy, nic, tylko wchodzić! Ale zaraz, zaraz... powrót nie będzie już taki łatwy! Jest to, jak widzimy, raczej czarny humor - przypominający skądinąd znaną scenę z Żab Arystofanesa, w której Dionizos z Heraklesem snują ironiczne rozważania na temat najprostszych sposobów przejścia na tamten świat. Sybilla drwi sobie wyraźnie z Eneasza, bo przecież nie o takie „łatwe” metody dotarcia do zaświatów bohaterowi chodziło; wróżbitka natychmiast zresztą zmienia ton i treść swojej porady, wskazując na złotą gałąź jako właściwy środek ułatwiający podróże do krainy zmarłych. $\mathrm{Na}$ tym sarkastyczne wyskoki Sybilli jednak się nie kończą; jej najwyraźniej wolno więcej niż innym, bo w dość specyficzny sposób przedstawia królową zaświatów w rozmowie z Charonem: „niech sobie czysta Prozerpina siedzi w domu stryja” („casta licet patrui servet Proserpina limen”; VI 402) - niby czysta, a zadaje się ze stryjem... Taką właśnie interpretację - wskazującą na złośliwą ironię Sybilli, która stara się podkreślić kontrast między „czystością” obowiązującą boginię niczym rzymską matronę a kazirodczym związkiem, który jej przypadł w udziale - zaproponował niedawno Lee Fratantuono w artykule na temat Persefony w Eneidzie ${ }^{10}$; byłbym jednak w tym przypadku sceptyczny, bo czy rzeczywiście Sybilla miałaby jakiś powód, by szydzić z Prozerpiny, skoro związki między bogami w ogóle wyglądają siłą rzeczy inaczej niż w przypadku ludzi, a poza tym czy jest sens podrwiwania z czyjegoś związku, do którego się raczej ten ktoś nie garnął?

Pewnego rodzaju, również niezbyt stosownego, dowcipu doszukiwano się także w słynnych słowach Eneasza skierowanych do ducha Dydony w zaświatach: ,ja wbrew sercu żegnałem twoje wybrzeże, królowo...”: (,invitus regina tuo de litore cessi”, VI 460). Usprawiedliwienie bowiem, które Eneasz serwuje Dydonie, stanowi, jak wiadomo, parafrazę zdania z poematu Katullusa o warkoczu królewny Bereniki przeniesionym do nieba (,invita, o regina, tuo de vertice cessi"; 66, 39) - a więc tam, gdzie spodziewalibyśmy się wyłącznie powagi i patosu, mamy do czynienia przynajmniej z pewnym obniżeniem tonu,

też nie są całkowicie wolne od komicznych naleciałości; vide np. Seidensticker 1982 (w monografii tej jeden rozdział został zresztą poświęcony Homerowi, traktowanemu jako prekursor tragediopisarzy również na gruncie „komicznym”).

${ }^{10}$ Fratantuono 2012: 427: ,the language used to describe the god's bride is deliberately provocative. Casta refers harmlessly enough to the attitude one would expect from a proper Roman wife; patrui rathers ruins the chastely noble context by underscoring the incestuous nature of the union. Proserpina, Deiphobe rather sarcastically seems to note, may continue to be the dutiful spouse of her uncle". 
ponieważ w hierarchii gatunków epos heroiczny stał wyżej od (nazwijmy to tak anachronicznie) epyllionu ${ }^{11}$. Trzeba też pamiętać, że Dydona w chwili agonii traci pukiel swoich włosów, ścięty przez Irydę jako znak oddzielenia duszy od ciała. Sytuacje Bereniki i Dydony są zarazem podobne i dramatycznie odmienne: po jednej stronie mamy katasteryzm (w panegirycznej oprawie), po drugiej przedwczesną śmierć; obydwa zjawiska związane z włosami. Poświęcono temu fenomenowi mnóstwo komentarzy, mówiono o apoteozie, panegiryzmie, wierze Eneasza w powrót Dydony do świata żywych, czy też (po prostu) o aleksandryjskiej aluzyjności albo nawet czystym przypadku... ${ }^{12}$. Dla odbiorcy, który jest świadomy kontekstu, Eneasz przemawia mniej więcej tak (o ile przyjmiemy, że na chwilę została zniweczona iluzja „efektu realności”, którą zastąpiła czysta tekstualność): „Poznajecie? To z tego znanego wierszyka o warkoczu; pasuje, bo przecież Dydonie też trochę włosów zniknęło, kiedy przenosiła się w zaświaty...". Tego rodzaju aluzje nie mogą mieć rzecz jasna wpływu na relacje między samymi postaciami Eneasza i Dydony; efektem owego zabiegu było natomiast rozpoznawalne dla odbiorców szyderstwo ze związku afrykańskiej królowej z proto-Rzymianinem, wymierzone pośrednio w pseudo-małżeństwo Antoniusza z Kleopatrą ${ }^{13}$.

Takich sarkastycznych czy złośliwych wypowiedzi można w Eneidzie z pewnością znaleźć więcej; padają one zwłaszcza w ferworze walki. Przypomnieć w związku z tym można na przykład złośliwą radę Pyrrusa skierowaną do ginącego Priama, aby poskarżył się Achillesowi w zaświatach na niewłaściwe zachowanie syna (,referes ergo haec et nuntius ibis Pelidae genitori”; II 547548) czy słowa Turnusa, który rzucając wyzwanie jednemu z Trojan, Pandarosowi, zapowiada: „zaraz będziesz mógł opowiedzieć Priamowi, że spotkaliście tu kolejnego Achillesa”... („Hic etiam inventum Priamo narrabis Achillem”; IX 742) $)^{14}$.

Tak się składa, że wszystkie te (nazwijmy to tak) żarty mają wspólną cechę: są związane w jakiś sposób ze śmiercią. Ale nie musi to bynajmniej oznaczać, że specjalnością Wergiliusza był czarny humor. Raczej chodzi tutaj o dopasowanie ironicznego tonu do powagi tematu, a więc wierność zasadzie stosowności. Mamy humor, ale paradoksalnie - poważny. Można wobec tego stwierdzić, że mimo wątpliwości wyrażanych niekiedy przez komentatorów, tego typu ironiczne czy sarkastyczne inkrustacje w zasadniczy sposób nie podważają epickiej

\footnotetext{
${ }^{11}$ Cytowany już tutaj badacz używa w tym kontekście terminów „burleska” i „komedia”; vide Fratantuono 2012: 428.

${ }^{12}$ Vide np. Johnston 1987; Smith 1993.

${ }^{13}$ Vide Fratantuono 2012: 428.

${ }^{14}$ Tego typu wypowiedzi, niosące ze sobą pewną dozę przechwałki, stanowią stały element bitewnej retoryki w epickiej tradycji, począwszy oczywiście od Iliady (vide np. Kyriakou 2001; Minchin 2010: 388, 395; 398). Głównie też takimi przykładami agresywnego sarkazmu posługuje się w swoim porównaniu humoru Homeryckiego i Wergiliańskiego Hewitt (1929).
} 
wymowy tekstu. Nic dziwnego zatem, że jednej ze scen Eneidy, ukazującej Eneasza, który w świecie umarłych usiłuje stoczyć pojedynek $\mathrm{z}$ widmowymi potworami, nadano oksymoroniczne miano ,infernalnej komedii" ${ }^{15}$.

Nieco inaczej, jak się wydaje, funkcjonują właśnie komediowe, a nie komiczne (czy humorystyczne) składniki Eneidy - jak widzieliśmy, w ogóle raczej trudno by było szukać tu scen, które wzbudzałyby po prostu śmiech, zdarzają się natomiast miejsca, w których pewien ironiczny dystans wobec przedstawianych wydarzeń jest zaznaczany przez przywołanie konwencji znanych $\mathrm{z}$ antycznej komedii. Komedia jednak to nie wszystko - może nawet, jak się za chwilę okaże, istnieją w Eneidzie również aluzje do bardziej frywolnego gatunku, jakim jest obsceniczny mim. Zakłócenie następuje zatem w tym przypadku na poziomie relacji z archetekstem, ma wobec tego głębszy zasięg i poważniejsze konsekwencje. Sięgnijmy po przykłady.

Pierwsze dwa pochodzą z księgi pierwszej i dotyczą, kolejno, aposiopesis Neptuna (Aen. I 135: „quos ego...!”) oraz spotkania Eneasza ze swoją matką, Wenus (I 314-409) - na obcym, kartagińskim terytorium. Słynna eksklamacja Neptuna była zwykle traktowana jako popis retoryczny ${ }^{16}$, a więc wtręt prozatorski; Roland Austin w swoim komentarzu do pierwszej księgi Eneidy zauważa jednak, że niedokończone zdanie wyrażające groźbę wyraźnie znamionuje emocje komediowe ${ }^{17}$. Istotnie, emfatyczne pogróżki we fragmentarycznej formie to rzecz znana z pewnością wielu komediom ${ }^{18}$.

Jeśli chodzi o ten drugi, znacznie bardziej skomplikowany przykład, wiele miejsca w komentarzach poświęcono wyjaśnieniu, dlaczego Wenus ukrywa się przed swoim synem (albo dlaczego, skoro już zdecydowała się ukrywać, nie ukrywa się konsekwentnie do końca). Wskazywano przy tym oczywiście na analogiczną scenę z Odysei - choć różnice w tym przypadku wydają się równie istotne, co podobieństwa. Trudno przecież nie zauważyć, że spotkanie Eneasza z Wenus jest niczym innym, jak komediową przebieranką skutkującą efektem qui pro quo. Pomysłowość tej sceny polega na tym, że Eneasz zwraca się do przebranej Wenus wypowiadając komplement, który ma wartość w odniesieniu do zwykłej istoty, a nie bogini - tak jak to ma miejsce we wzorcowej scenie spotkania Odyseusza z Nauzykaą - nazywa po prostu napotkaną osobę „,boginią”. Tymczasem komplement trafia do bogini rzeczywistej, która tylko udaje śmiertelniczkę. Jako komplement słowa Eneasza są więc w zasadzie niewypałem, ale przypadkiem trafiają w sedno. Na tym jednak nie koniec zamieszania. Przebrana Wenus, tłumacząc niejako Eneaszowi swoją samotną obecność na pustkowiu,

${ }^{15}$ „In a moment of infernal comedy Aeneas draws his sword to attack the terrifying phantom monsters, and has to be warned by the Sibyl of the futility of striking at shadows" (Hardie 2014: 42).

\footnotetext{
${ }^{16}$ Vide np. Brower 2010: 276.

${ }^{17}$ Vide Austin 1971: 66.

${ }^{18}$ Vide Morris 1889: 411-412; Karakasis 2005: 5.
} 
wypytuje go o siostry, które rzekomo mają jej towarzyszyć, tylko gdzieś się akurat zagubiły (Aen. I 321-324):

\begin{abstract}
'Heus' inquit 'iuvenes, monstrate mearum vidistis si quam hic errantem forte sororum, succinctam pharetra et maculosae tegmine lyncis, aut spumantis apri cursum clamore prementem.'
\end{abstract}

Oczywiście w istocie żadnych sióstr w pobliżu nie ma, ale jest to kolejny sygnał, że mamy do czynienia ze sceną komediową - motyw zmyślonych sióstr jest znany z niejednej komedii ${ }^{19}$. Ponadto Wenus zwraca się do Eneasza i Achatesa per iuvenes, odmładzając ich nieco być może przy tym, ale też posługując się nazwą typowego charakteru komediowego ${ }^{20}$. Następująca później opowieść o losach Dydony, dość ogólnie dramatycznych zresztą, zawiera również pewną aluzję komediową, jak zauważył jeden $\mathrm{z}$ badaczy ${ }^{21}$. I wreszcie zakończenie całej sceny, najbardziej może wymowne. Pojawia się tu pewna dwuznaczność - mowa jest bowiem o tym, że z Wenus opada szata. Niektórzy chcieli to rozumieć tak, że ponieważ w opisanym przez Wergiliusza przebraniu Wenus miała krótko podkasaną spódniczkę, spódniczka ta na końcu opada i w ten sposób zasłania nogi. Wenus zatem zmienia się ze zwykłej młodej dziewczyny w dostojną boginię i zyskuje przyzwoitą szatę aż do kostek. Inni, nieco śmielsi badacze, sugerują, że Wenus, stosownie do swojego tradycyjnego emploi, pojawia się w ostatniej chwili bez ubrania, które w całości spada jej do stóp ${ }^{22}$. Jakkolwiek by było (a nie jest przecież wykluczone, że w tekście pojawia się - jak to nieraz bywa u Wergiliusza - celowa dwuznaczność i każdy może sobie widzieć to, na co ma ochotę), jeszcze jedno przynajmniej znaczenie może towarzyszyć owemu gestowi - Wenus zrzuca tutaj kostium i schodzi po prostu ze sceny. Występ się skończył, finita est comoedia, plaudite! Kończy się też natychmiast ton komediowy - zamiast aplauzu, czekają Wenus gorzkie wyrzuty ze strony Eneasza, któremu najwyraźniej występ ten nie przypadł do gustu („Quid natum totiens, crudelis tu quoque, falsis / ludis imaginibus?". Zwróćmy uwagę na słowa ludo oraz imago, które odsyłają nas ponownie do kontekstu komediowo-mimicznego; Imago to tytuł jednego z mimów Laberiusza). Można zrozumieć, że bohaterowi

\footnotetext{
${ }^{19} \mathrm{Z}$ antycznych utworów komediowych należałoby tu wymienić Zjawę Menandra i Żolnierza Samochwała Plauta; podobny motyw występujący w Szekspirowskim Wieczorze Trzech Króli można natomiast uznać za przykładowy dowód na to, że i w późniejszych czasach komedia sięgała po te same pomysły.

${ }^{20}$ Nazwa ta zwykle brzmiała adulescens, ale np. Kwintylian używa w tym kontekście określenia iuvenes właśnie: „Itaque in fabulis iuvenum senum militum matronarum gravior ingressus est [...]" (Inst. orat. XI 3, 111).

${ }^{21}$ Vide Lloyd 1977: 252. Chodzi tu o motyw zdobytego podstępem złota, występujący m.in. w komedii Plauta Mostellaria.

${ }^{22} \mathrm{Na}$ temat obu tych interpretacji vide Reckford 1995-1996: 1-3. Cf. także Ahl 2012: 14.
} 
znajdującemu się na nieznanym lądzie bynajmniej nie jest do śmiechu, więc trudno mu docenić efektowny skądinąd popis umiejętności scenicznych jego matki. Ale reakcja Eneasza ma też być może walor metatekstowy - epicki bohater $\mathrm{z}$ niesmakiem przyjmuje ten niestosowny, nie-epicki wtręt komediowy w dziele należącym do wysokiego gatunku (,przypominam, że jestem bohaterem epickim! Nie życzę sobie...” itd.).

W Eneidzie znajdziemy też scenę poniekąd odwrotną, w której to, co ponure, zostaje obrócone w żart. Chodzi o przepowiednię wygłoszoną przez Celeno, jedną z Harpii, przepowiednię dotyczącą głodowania, które zmusi trojańskich uchodźców do jedzenia stołów (III 245-258). Harpie są poniekąd specjalistkami od wywoływania klęski głodu, więc brzmi to dość wiarygodnie i nie może napawać optymizmem. Pewna nadzieja dla tułaczy wynika jedynie stąd, że, jak wiemy, pomyślnie brzmiące przepowiednie zwykle oznaczają fatalne zdarzenia; co prawda, źle brzmiące przepowiednie oznaczają zwykle to samo, ale w Eneidzie zdarzają się od obydwu tych zasad wyjątki. Taki wyjątek właśnie dotyczy owej ponurej przepowiedni, która okazuje się ostatecznie nie tak groźna, jak z początku sądzono, a autorem żartu o „zjadanych stołach” (prototypie dzisiejszej pizzy, jak niektórzy chcą, nieco chyba na wyrost, jak sądzę ${ }^{23}$ ) jest dziecko - Askaniusz (,heus, etiam mensas consumimus? inquit Iulus, / nec plura, adludens”; VII 116-117) ${ }^{24}$. Warto zauważyć, że ten moment eksplozji dziecięcej wyobraźni jest czymś wyjątkowym w poezji antycznej; to w istocie „pierwszy przykład dziecięcego humoru w literaturze europejskiej", jak chce Jenkyns ${ }^{25}$; inny współczesny interpretator Eneidy uznał to nawet za przykład ,uczniowskiego humoru” (,schoolboy humour" ${ }^{26}$. Wątek ten można jednak również potraktować jako przykład swoistej komediowej perypetii, w której to, co przykre, zmienia się nieoczekiwanie na pomyślne, przy akompaniamencie wybuchów śmiechu ${ }^{27}$.

Powyższe przykłady pochodzą, co warto zaznaczyć, z tych ksiąg Eneidy, które były ogółem uważane (słusznie lub nie, to rzecz dyskusyjna) za nieco „lżejsze” w tonie, a zaliczano do nich księgi o nieparzystych numerach ${ }^{28}$. Za pewną osobliwość należy wobec tego uznać fakt, że postać, której najłatwiej

${ }^{23}$ Vide Ades 1969. Cf. ponadto Lawrence 2013.

${ }^{24}$ Opinie badaczy na temat żartu Askaniusza zebrał Merriam 2002: 857. Cf. także Rogerson 2017: 169-180.

${ }^{25}$ Jenkyns 1998: 501

${ }^{26}$ Heinze 1993: 220.

${ }^{27}$ Podobny zbiorowy wybuch śmiechu wśród Trojan towarzyszy w Eneidzie epizodowi związanemu z wyścigiem okrętów, kiedy to sternik Menetes, wyrzucony złośliwie za burtę przez swojego zirytowanego towarzysza, z trudem się wydostaje z morskich fal plując przy tym słoną wodą (vide Aen. V 181-182).

${ }^{28}$ Vide Duckworth 1960: 186 (autor broni tu tezy o jednym z trzech zasadniczych strukturalnych schematów, na których oparta jest kompozycja Eneidy; polega on na: „The alternation of the books, those with even numbers being of a more serious and tragic nature than those with odd numbers, which are lighter and serve to relieve the tension"). 
przypisać komediową proweniencję, pojawia się w księdze „parzystej”, na dodatek tej, która przedstawia jeden z najbardziej wstrząsających epizodów całej fabuły eposu, czyli zagładę Troi. Postać owa to Sinon, grecki „agent”, który oszukuje Trojan w stylu przywodzącym na myśl zachowanie typowe dla komediowej figury określanej jako sprytny niewolnik, servus callidus. Poza najistotniejszym w tym przypadku krętactwem inną cechą, która pozwala rozpoznać komediowe rysy tej postaci, jest połączone z owym krętactwem greckie pochodzenie $^{29}$. W najnowszym komentarzu do drugiej księgi Eneidy możemy ponadto naleźć wzmiankę o tym, że sam monolog Sinona zawiera pewną aluzję do komedii, Sinon sugeruje bowiem, że przyłączył się do armii greckiej idącej pod Troję z powodu doskwierającego jego rodzinie ubóstwa (,,pauper in arma pater primis huc misit ab annis"; II 87), a jest to motywacja, jaka często towarzyszy właśnie komediowym bohaterom wstępującym do wojska ${ }^{30}$.

Kolejny, dość kontrowersyjny przykład znajduje się w księdze VIII, a dotyczy spotkania Eneasza z Ewandrem. Podejrzane roztargnienie Ewandra oraz jego skłonność do koncentrowania się na wyglądzie zewnętrznym Eneasza dowodzą, że w tej scenie doszło do głosu niekłamane i bardzo głębokie uczucie, łączące niegdyś Ewandra z ojcem Eneasza, Anchizesem ${ }^{31}$. Wergiliusz wygrywa tutaj komiczny kontrast między powagą misji Eneasza a bardziej przyziemnymi, miłosnymi zainteresowaniami Ewandra; ponadto homoerotyczny wydźwięk sceny sugeruje, że mamy tu do czynienia z konwencjami, które wywodzą się $\mathrm{z}$ bardzo niskich rejonów literatury, a mianowicie ze scenicznego mimu.

W tej samej księdze, która może tym samym uchodzić za najbardziej komediową w całym utworze, pojawia się sławna (czy też właśnie niesławna, jak chcieliby niektórzy) i także wielokrotnie na różne sposoby interpretowana, problematyczna scena uwiedzenia Wulkana przez Wenus ${ }^{32}$. Już antyczni komentatorzy, tacy jak Serwiusz czy Makrobiusz, nie mogli w to uwierzyć: jak Wenus mogła prosić własnego, „legalnego" męża o podarunek dla swojego nieślubnego syna? Warto przypomnieć, że Makrobiusz (Sat. I 24 6-7) uznał nawet, iż właśnie ta jedna niesmaczna scena zadecydowała o tym, że Wergiliusz na łożu śmierci zażądał spalenia Eneidy. W domyśle: stworzył tę scenę najwyraźniej w chwili słabości (no cóż, nawet Wergiliusz się czasami zdrzemnie), ale na pewno by

\footnotetext{
${ }^{29}$ Można oczywiście zauważyć, że w przedstawianych przez Wergiliusza realiach wojny trojańskiej Sinon nie mógłby być nikim innym jak tylko Grekiem, ale jednocześnie trzeba przyznać, że fakt ten został wykorzystany do wprowadzenia w obręb eposu stereotypowych cech komediowej „greckości”. Stereotyp kłamliwego Greka w komediach rzymskich (z odwołaniem zresztą do Wergiliuszowego Sinona) omawia Segal (1968: 37-38); na temat komediowego typu sprytnego niewolnika w ogóle vide Skwara 2001: 34, 86; 127.

${ }^{30}$ Vide Horsfall 2008: 115.

${ }^{31} \mathrm{~Np}$. Aen. VIII 152-153: ,ille os oculosque loquentis / iamdudum et totum lustrabat lumine corpus". Vide Lloyd 1999 (gdzie mowa jest zresztą głównie o epickich paralelach dla tej sceny).

${ }^{32} \mathrm{Na}$ temat interpretacji owej sceny oraz jej komediowych komponentów vide Smolenaars 2004, a także Lloyd 1977: 253 oraz Ahl 2012: 20-21.
} 
ją ekspurgował z dzieła, gdyby tylko zdążył je poprawić. Nie zdążył, a zatem postanowił w celu ratowania, jak sugeruje Makrobiusz, swojej reputacji, powierzyć Eneidę płomieniom, jakby ku przebłaganiu bóstwa władającego ogniem, bo w tej frywolnej scenie nie kto inny jak Wulkan został obrażony. Może i tak - ale scena ta, mimo swojej niestosowności, doskonale łączy się z innymi ważnymi motywami obecnymi w VIII księdze, a nawet w całym utworze. Może istotnie należałoby spalić bez reszty dzieło, w którym zagnieździł się ów ekspansywny, a wysoce niestosowny motyw?

Wulkana powinniśmy sobie wyobrazić, jak nalega Wergiliusz, w roli kobiety - a więc mamy tu do czynienia z kolejną deprecjonującą przebieranką, tak charakterystyczną dla konwencji komediowej:

Inde ubi prima quies medio iam noctis abactae curriculo expulerat somnum, cum femina primum, cui tolerare colo vitam tenuique Minerva impositum, cinerem et sopitos suscitat ignis

noctem addens operi, famulasque ad lumina longo

exercet penso, castum ut servare cubile

coniugis et possit parvos educere natos:

haud secus ignipotens nec tempore segnior illo

mollibus e stratis opera ad fabrilia surgit.

Jak na dłoni widać tu ironię zahaczającą - po raz kolejny, chciałoby się powiedzieć - o złośliwość: Wulkan został nie tylko porównany do kobiety, ale do żony podtrzymującej ognisko, rozumiane jako najważniejsza część domu, która gwarantuje harmonię oraz czystą, niezakłóconą miłość między zamieszkującymi go małżonkami. Jak w rzeczywistości wyglądało małżeństwo Wulkana z Wenus, wszyscy doskonale wiemy. A przecież w ogniu tej podstępnej, dwuznacznej miłości, przypomnijmy, wykuwana była tarcza dla Eneasza - symbol dumy i potęgi przyszłego Rzymu... Poszlibyśmy być może nieco za daleko podejrzewając, że mamy tu do czynienia z sarkastycznym komentarzem do chroniącego małżeństwa ustawodawstwa Augustowskiego, ale wspomniany passus Eneidy z pewnością nie wspierał tego typu posunięć legislacyjnych.

Poszukiwania w tekście Eneidy rozmaitych mniej lub bardziej zawoalowanych „podtekstów”, w tym również tych komediowych czy komicznych, nie zakończą się z pewnością na powyżej przytoczonych przykładach; w oczekiwaniu na kolejne odkrycia $w$ tej dziedzinie warto jednak już teraz zadać zasadnicze pytanie: jaki ewentualnie wpływ owe inkrustacje mogą mieć na interpretację całości utworu?

Dzieje badań nad Eneida to w pewnej mierze seria prób znalezienia jakiejś trafnej, zwięzłej formuły opisującej dzieło poety, typu: „Eneida jako rzymska wersja Iliady i Odysei”, ,Eneida jako aition rodu Oktawiana” (jak to ujmował Serwiusz: „intentio Vergilii haec est, Homerum imitari et Augustum laudare 
a parentibus”; ad Aen. I prooem.). Formuła „Eneida jako komedia” nie przyjęłaby się chyba jednak, jak można podejrzewać, zbyt łatwo. Równie istotne dla tych dziejów były jednak ponadto interpretacje usiłujące ustalić, czy Eneida ma raczej optymistyczny czy też może pesymistyczny wydźwię ${ }^{33}$; ta debata wydaje się już wprawdzie nieco przebrzmiała, ale przekonanie o istnieniu w tekście komediowych ingrediencji wzmacniałoby z pewnością, siłą rzeczy, argumentację „optymistów”.

Wspomniałem wcześniej o relacjach z archetekstem gatunkowym jako istotnym składniku znaczeniowego uniwersum Eneidy. Otóż związane jest to $\mathrm{z}$ nowszą dyskusją na temat funkcjonowania gatunków literackich w systemie literatury rzymskiej (czy szerzej: antycznej). Nie istnieją utwory gatunkowo „czyste” - to poniekąd truizm, w dodatku dotyczący całej literatury; jeden z jej teoretyków stwierdził: „Tak, jak nie ma tekstów pozagatunkowych, tak też nie ma utworów podpadających całkowicie pod normy wyłącznie jednego gatunku"34. Dawno już jednak zauważono, że poeci epoki augustowskiej mają szczególną predylekcję do mieszania gatunków literackich, tworzenia hybryd gatunkowych ${ }^{35}$. Elegie i eklogi wypróbowujące ton epicki ${ }^{36}$, satyra nasycona treściami teoretyczno- i krytycznoliterackimi, wierszowany kalendarz czy nieokreślone perpetuum carmen w wykonaniu Owidiusza ${ }^{37}$ - to chyba najbardziej spektakularne przykłady tej praktyki. Jeśli chodzi o Eneidę, to rzecz jasna dostrzegano w niej od dawna elementy epyllionu, tragedii, konwencje typowe dla historiografii ${ }^{38}$, wtręty bukoliczne wreszcie; istnieje nawet teoria, że Eneida jest swoistą rekapitulacją wcześniejszej twórczości Wergiliusza - stąd poza odniesieniami do bukolik ważna funkcja labores, stanowiących aluzję do Georgik. Ale komedia albo mim? To wydaje się przekraczać granice decorum. Znana jest jednakowoż opinia Serwiusza, który sądził, że cała księga IV Eneidy jest zasadniczo „komediowa”, ponieważ jej tematem jest „nieepicka” miłość (charakterystyczne, że współcześni badacze właśnie w tej księdze najczęściej

${ }^{33}$ Vide Harrison 1990: 1-20. Najbardziej wpływową „optymistyczną” interpretację Eneidy znaleźć można w: Pöschl 1950; za najbardziej z kolei znaną monografię z kręgu szkoły „pesymistów" uchodzi Lyne 1987. Nie brak oczywiście ujęć, które akcentują przede wszystkim ambiwalentny ton Eneidy; vide np. Perret 1967; O’Hara 1986.

${ }^{34}$ Nycz 1995: 70-71.

${ }^{35}$ Analizie tej tendencji w twórczości dwóch poetów augustowskich poświęcona została osobna książka; vide Harrison 2007.

${ }^{36}$ Vide np. Van Sickle 1978: 101-142; O’Rourke 2010.

${ }^{37} \mathrm{Nie}$ sposób nie zauważyć, że podczas lektury Metamorfoz znajdujemy się w specyfícznym, „Owidiuszowym” świecie, w którym niewiele mogą nam pomóc etykietki typu „elegia” czy „epos”. Można się również upierać, że mamy tu do czynienia z wyrafinowaną grą elementami epiki i elegii. Niedawno pojawiła się też np. propozycja interpretowania Metamorfoz jako poematu dydaktycznego (a właściwie: pseudo-dydaktycznego); vide Barone 2017.

${ }^{38} \mathrm{O}$ skłonności Wergiliusza do łączenia konwencji epickich z tragediowymi i historiograficznymi pisała m.in. Rossi (2004). 
znajdowali podteksty tragediowe $)^{39}$. Komediowe alikwoty w innych księgach eposu nie tyle jednak wzmacniają „nieepicki” wydźwięk całości, ile raczej wskazują na spotęgowaną samoświadomość twórcy, który stara się poszerzać pole intertekstualnej gry z odbiorcą nie rezygnując przy tym nawet z sięgania po narzędzia formalnie wykraczające poza estetyczną stosowność. I chociaż Wergiliusz - w porównaniu do Owidiusza choćby - nie jest traktowany jako zapamiętały innowator, to heroiczny epos zabarwiony gdzieniegdzie komediowymi detalami należy z pewnością do śmiałych gatunkowych eksperymentów literackich owych czasów.

\section{BIBLIOGRAFIA}

Teksty źródłowe

Fragmenta Poetarum Latinorum Epicorum et Lyricorum Praeter Enni Annales et Ciceronis Germanicique Aratea, post W. Morel et K. Büchner editionem quartam auctam curavit J. Blänsdorf, Bibliotheca Teubneriana, Berlin-New York 2011.

P. Vergilius Maro, Aeneis, rec. G.B. Conte, Bibliotheca Teubneriana, editio altera, Berlin-Boston 2019.

Opracowania

Ades 1969: J.I. Ades, Vergil (or Aeneas) et Pizza, „Classical Journal” LXIV (1969), nr 6, 268.

Ahl 2012: F. Ahl, Humour, Chance, and Choices: Human and Divine in the Aeneid, w: Götter und menschliche Willensfreiheit: Von Lucan bis Silius Italicus, Hrsg. Th. Baier, München 2012, $13-28$.

Anderson 1981: W.S. Anderson, Servius and the 'Comic Style' of Aeneid 4, „Arethusa” XIV (1981) $\mathrm{nr} 1,115-125$.

Austin 1955: R.G. Austin, Introduction, w: R.G. Austin, Virgil: Aeneid IV, Oxford 1955.

Austin 1971: R.G. Austin, Aeneidos liber primus, Oxford 1971.

Barone 2017: C. Barone, Omnia mutantur, nihil interit. Un epos pseudo-didascalico sul mondo in trasformazione, Palermo 2017.

Bell 2007: R.H. Bell, Homer's Humor: Laughter in The Iliad, „Humanitas” XX (2007), nr 1-2, 96-116.

Bourquin 2019: Ch. Bourquin, Humor in der Aeneis: Ein rezeptionstheoretischer Versuch, Berlin 2019.

${ }^{39}$ Servius, ad Aen. IV 1: ,paene comicus stilus, nec mirum ubi de amore tractatur”. Na temat specyficznej „komediowości” w ujęciu Serwiusza vide Anderson 1981: 115-125. O Dydonie jako heroinie tragediowej vide (przykładowo): DeGraff 1932: 148-150; Austin 1955: ix-xix_x; Fantham 1975: 1-10. Co ciekawe, w Eneidzie znaleźć można przynajmniej dwie wyraźne metatekstowe wskazówki dotyczące wyraźnie „teatralnego” charakteru kartagińskich epizodów z Dydoną w roli głównej; vide Farrell 2012: 296-297.

Nie zaszkodzi w tym miejscu przypomnieć, że jedno z najbardziej „zapatrzonych” w Eneide dzieł literatury europejskiej nosi tytuł Boska Komedia (choć znaczenie tego pozornie genologicznego terminu jest tutaj dość odległe od jego antycznych korzeni). Dante znał wprawdzie komentarz Serwiusza do Eneidy (vide von Richthofen 1974: 117-128), w którym mowa jest przecież o „komicznym stylu” IV księgi Wergiliuszowego eposu, ale nie sposób stwierdzić, czy ta konstatacja miała jakikolwiek wpływ na „komediową” identyfikację dzieła Dantego. 
Brower 2010: R.A. Brower, Visual and Verbal Translation of Myth: Neptune in Vergil, Rubens, and Dryden, w: A Companion to Vergil's Aeneid and Its Tradition, eds. J. Farrell, M.C.J. Putnam, Malden 2010.

Clarke 1969: H.W. Clarke, The Humor of Homer, „Classical Journal” LXIV (1969), nr 6, 246-252.

Clarke 2007: J.R. Clarke, Looking at Laughter: Humor, Power, and Transgression in Roman Visual Culture, 100 B.C.- --A.D. 250, Berkeley-Los Angeles 2007.

Coleman 1975: R. Coleman, Vergil's Pastoral Modes, „Ramus” IV (1975), nr 2, 140-162.

de Vos 1991: M. de Vos, La fuga di Enea in pitture del 1 secolo D.C., „Kölner Jahrbuch für Vor- und Frühgeschichte” XXIV (1991), 113-123.

DeGraff 1932: Th.B. DeGraff, Antigone and Dido, „Classical Weekly” XXV (1932), nr 19, 148-150.

DeWitt 1930: N.W. DeWitt, Vergil and the Tragic Drama, „Classical Journal” XXVI (1930), nr 1, $19-27$.

Duckworth 1960: G.E. Duckworth, Mathematical Symmetry in Vergil's Aeneid, „Transactions and Proceedings of the American Philological Association" XCI (1960), 184-220.

Dziemidok 2011: B. Dziemidok, O komizmie. Od Arystotelesa do dzisiaj, Gdańsk 2011.

Fantham 1975: E. Fantham, Virgil's Dido and Seneca's Tragic Heroines, „Greece \& Rome” XXII (1975), nr 1, 1-10.

Farrell 2012: J. Farrell, Art, Aesthetics, and the Hero in Vergil's Aeneid, w: Aesthetic Value in Classical Antiquity, eds. I. Sluiter, R.M. Rosen, Leiden-Boston 2012, 285-313.

Fratantuono 2012: L. Fratantuono, ,, Nondum Proserpina abstulerat”: Persephone in the Aeneid, „Revue des Études Anciennes” CXIV (2012), nr 2, 423-434.

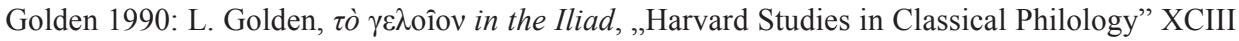
(1990), 47-57.

Griffith, Marks 2007: R.D. Griffith, R.B. Marks, A Funny Thing Happened on the Way to the Agora: Ancient Greek and Roman Humour, Kingston 2007.

Halperin 1983: D. Halperin, Before Pastoral: Theocritus and the Ancient Tradition of Bucolic Poetry, New Haven-London 1983.

Hanssen 1948: J.S.Th. Hanssen, Virgilian Notes, „Symbolae Osloenses” XXVI (1948), nr 1, 93-125. Hardie 2014: Ph. Hardie, The Last Trojan Hero. A Cultural History of Virgil's Aeneid, LondonNew York 2014.

Harrison 1990: S.J. Harrison, Some Views of the Aeneid in the Twentieth Century, w: Oxford Readings in Vergil's Aeneid, ed. S.J. Harrison, Oxford-New York 1990.

Harrison 2007: S.J. Harrison, Generic Enrichment in Vergil and Horace, Oxford 2007.

Heinze 1993: R. Heinze, Virgil's Epic Technique, trans. H. Harvey, D. Harvey, F. Robertson, London 1993.

Hewitt 1929: J.W. Hewitt, Humor in Homer and in Vergil, „Classical Weekly”, XXII (1929), nr 22-23, 169-172, 177-181.

Horsfall 2008: N. Horsfall, Virgil, Aeneid 2: A Commentary, Leiden-Boston 2008

Jackson 1914: C.N. Jackson, Molle Atque Facetum, „Harvard Studies in Classical Philology” XXV (1914), 117-137.

Jenkyns 1993: R. Jenkyns, Labor Improbus, „Classical Quarterly” XLIII (1993), nr 1, 243-248.

Jenkyns 1998: R. Jenkyns, Virgil's Experience: Nature and History; Times, Names, and Places, Oxford 1998.

Johnston 1987: P.A. Johnston, Dido, Berenice, and Arsinoe: Aeneid 6.460, „American Journal of Philology" CVIII (1987), No.nr 4, 649-654.

Karakasis 2005: E. Karakasis, Terence and the Language of Roman Comedy, Cambridge 2005.

Kick 2014: Kanon graficzny I. Od Gilgamesza do Tybetańskiej księgi umartych, red. serii R. Kick, przeł. D. Kozińska, Warszawa 2014.

Korpanty 2007: J. Korpanty, Vergiliana: I. Horatianum illud molle atque facetum quid significet, II. De Turno observationes aliquot, III. De arte poetica in Aeneidis epilogo conspicua, „Classica Cracoviensia” XI (2007), 199-230. 
Kyriakou 2001: P. Kyriakou, Warrior Vaunts in the Iliad, „Rheinisches Museum für Philologie” CXLIV (2001), H. 3/4, celowy zapis? 250-277.

Lawrence 2013: C. Lawrence, How Aeneas Invented Pizza http://www.wondersandmarvels. com/2013/12/how-aeneas-invented-pizza.html (dostęp: 08.05.2019).

Lloyd 1977: R.B. Lloyd, Humor in the Aeneid, „Classical Journal”, LXXII (1977), nr 3, 250-257.

Lloyd 1999: Ch. Lloyd, The Evander-Anchises Connection: Fathers, Sons, and Homoerotic Desire in Vergil's Aeneid, „Vergilius” XLV (1999), 3-21.

Lumsden 1937: S.G. Lumsden, Humour in Virgil, diss. McGill University, Montreal 1937.

Lyne 1987: R.O.A.M. Lyne, Further Voices in Vergil's Aeneid, Oxford 1987.

MacKay 1963: L.A. MacKay, Hero and Theme in the Aeneid, „Transactions and Proceedings of the American Philological Association" XCIV (1963), 157-166.

Martindale 2005: Ch. Martindale, Latin Poetry and the Judgement of Taste: An Essay in Aesthetics, Oxford 2005.

Merriam 2002: C.U. Merriam, Storm Warning: Ascanius'Appearances in the Aeneid, „Latomus” LXI (2002), nr 4, 852-860.

Minchin 2010: E. Minchin, From Gentle Teasing to Heavy Sarcasm: Instances of Rhetorical Irony in Homer's Iliad, „Hermes” CXXXVIII (2010), H. 4, 387-402.

Morris 1889: E.P. Morris, On the Sentence-Question in Plautus and Terence: First Paper, „American Journal of Philology” X (1889), No.nr 4, 397-436.

Nycz 1995: R. Nycz, Intertekstualność i jej zakresy: teksty, gatunki, światy, w: R. Nycz, Tekstowy świat. Poststrukturalizm a wiedza o literaturze, Warszawa 1995.

O'Hara 1986: J.J. O'Hara, Death and Optimistic Prophecy in the Aeneid, Ann Arbor 1986.

Ogle 1916: M.B. Ogle, Molle Atque Facetum, „American Journal of Philology” XXXVII (1916), nr 3, 327-332.

O'Rourke 2010: D. O'Rourke, Maxima Roma in Propertius, Virgil, and Gallus, „Classical Quarterly" LX (2010), nr 2, 470-485.

Panoussi 2009: V. Panoussi, Vergil's Aeneid and Greek Tragedy: Ritual, Empire, and Intertext, Cambridge 2009.

Peirano 2012: I. Peirano, The Rhetoric of the Roman Fake. Latin Pseudepigrapha in Context, Cambridge 2012.

Perret 1967: J. Perret, Optimisme et tragédie dans l'Eneide, Paris 1967.

Pöschl 1950: V. Pöschl, Die Dichtkunst Vergils: Bild und Symbol in der Aeneis, Innsbruck 1950.

Reckford 1995-1996: K. Reckford, Recognizing Venus (I): Aeneas Meets His Mother, „Arion” III (1995-1996), nr 2/3, 1-42.

Richard 1951 : M. Richard, Virgile, auteur gai, Paris 1951.

von Richthofen 1974: E. von Richthofen, Traces of Servius in Dante, „Dante Studies” XCII (1974), 117-128.

Rogerson 2017: A. Rogerson, Virgil's Ascanius: Imagining the Future in the Aeneid, Cambridge 2017.

Rose 1942: H.J. Rose, The Eclogues of Vergil, Berkeley-Los Angeles 1942.

Rossi 2004: A. Rossi, Contexts of War: Manipulation of Genre in Virgilian Battle Narrative, Ann Arbor 2004.

Segal 1968: E. Segal, Roman Laughter: The Comedy of Plautus, Cambridge 1968.

Seidensticker 1982: B. Seidensticker, Palintonos Harmonia. Studien zu komischen Elementen in der griechischen Tragödie, Göttingen 1982.

Sikes 1940: E.E. Sikes, The Humour of Homer, „Classical Review”, LIV (1940), nr 3, 121-127.

Skwara 2001: E. Skwara, Historia komedii rzymskiej, Warszawa 2001.

Smith 1993: R.A. Smith, A Lock and a Promise: Myth and Allusion in Aeneas' Farewell to Dido in Aeneid 6, „Phoenix” XLVII, (1993), No.nr 4, 305-312.

Smolenaars 2004: J.J.L. Smolenaars, A Disturbing Scene from the Marriage of Venus and Vulcan: Aeneid 8.370-415, „Vergilius” L (2004), 96-107. 
Tarrant 2007: R. Tarrant, Horace and Roman literary history, w: The Cambridge Companion to Horace, ed. S. Harrison, Cambridge 2007.

Van Sickle 1979: J. Van Sickle, The Design of Vergil's Bucolics, Roma 1978.

Vincenz 1989: Helikon sarmacki. Wątki i tematy polskiej poezji barokowej, red. A. Vincenz, Wrocław-Warszawa 1989.

Zanker 1999: P. Zanker, August i potęga obrazów, przeł. L. Olszewski, Poznań 1999.

\section{COMEDY IN VERGIL'S AENEID}

\section{Sum mary}

The "generic enrichment" is a notion employed recently in the interpretation of the poetry of the two Augustan authors, namely Horace and Vergil; it is based on the presumption that these poets were especially keen to "enrich" their works by crossing the boundaries of literary genres. As regards the Vergil's heroic, grave epic, what can be found particularly interesting is the fact that it apparently contains some comic components, i.e. the references to the "unserious" genre of comedy - indicated previously from time to time by some scholars, but not studied in their entirety. The present paper offers a review and examination of the most evident instances of the comic conventions in the Aeneid in order to reveal the possible influence of those very conventions on the reading of the Vergil's epic poem as a whole. 